injected contrast media, with the risk of displacing a fragment towards the thorax, would only seem justified if the fragment could be palpated.

The damaged Braunüle was subsequently connected to a disposable giving-set and transfusion under pressure simulated with the aid of a Martin's pump. After 2 minutes the cannula fractured $2 \mathrm{~cm}$. from the tip and the distal portion shot off. The cause of the fracture remains uncertain. It seems unlikely in view of the position (away from a joint) and the short period of use (under 2 hours) that it could be fatigue. A manufacturing fault, undetected on insertion, cannot be ruled out, but the possibility of the cannula's being nicked by the bevel of the needle on withdrawal seems the most probable cause.

Practical safeguards should include great care in the inspection, positioning, and insertion of the Braunüle, especially in the withdrawal of the needle. On removal of the cannula it should be examined and measured to ensure that it has been entirely recovered. The advisability of pressure-transfusion through such a unit must be open to question. The suggestion in a B.M.F. editorial that plastic materials for intravascular insertion should contain radio-opaque material should be implemented.

I would like to thank Mr. H. L. Cochrane and Dr. R. E. W. B. Comerford for permission to publish this case and the Medical Photographic and Radiological Departments of Charing Cross Hospital for their assistance.

-I am, etc.,

Fulham Hospital,
London W.6.

E. B. Lewis.

REPERENCES

1 Moncrief, J. A., Ann. Surg., 1958, 147, 166. Surg., 1963, 86, 177 .

Bennett, P. J., Brit. med. F., 1963, 2, 1252. Udwadia, T. E., and Edwards, A. E., Brit. med.
f., 1963, 2, i251.

s Moore, J. M., ibid., 1963, 2, 1472.

- Funke, T., Grove, J. H., and Lundenfeld, F. H.,

Brit. med. F., 1963, 2, 1218.

\section{Measles Vaccine}

SIR,-Dr. P. F. Benson and others (3 October, p. 851) show that significant progress is being made towards a safe and effective vaccine against measles, a disease which still has a high morbidity at all ages and a case fatality of over $1 \%$ in children under 1 year. It is hoped that future development will lower still further the reaction rate and also enable the measles vaccine to be incorporated successfully in a multiple antigenic vaccine, thus making its introduction into the already complicated immunization schedule for infants simple.

Clinical trials in children raise difficult ethical questions. Measles vaccine trials in the past have been criticized on this score. ${ }^{12}$ In this study some of the patients were children of the scientific and technical staff closely connected with the trial. Their participation must surely satisfy the most exacting ethical code. - I am, etc.,

The Royal Infirmary,
Huddersfield, Yorks.

\section{REFERENCES}

1 Pappworth, M. H., Twentieth Century, Autumn

1962, p. 66. 2. . Brit. med. F., 1963, 1, 264.

\section{Fatal Hyperpyrexia with Phenelzine and Imipramine}

SiR,-The frequency with which drugs used for treating psychogenic disorders may be combined leads us to report a further case of death due to hyperpyrexia $\left(43.2^{\circ} \mathrm{C}\right.$ or $110^{\circ} \mathrm{F}$.) caused by overdosage with Nardil (phenelzine, a monoamine-oxidase inhibitor) together with Tofranil (imipramine, a psychostimulant drug). ${ }^{1} \quad$ The danger of combining these two and related drugs has been reported by others, and symptoms include headache, mental agitation, tremor, convulsions, dyspnoea and cyanosis, abdominal pain, nausea, vomiting, labile blood-pressure, collapse, and death. ${ }^{2}$ Similar symptoms and death have followed the use of pethidine in patients taking phenelzine. ${ }^{34}$

A man aged 22 saw a psychiatrist on 13 November 1963 with an inadequate psychopathic picture and symptomatic alcoholism, and was treated with benefit by phenelzine $15 \mathrm{mg}$. t.d.s. for three months. After failing to keep two appointments he again saw the psychiatrist on 29 April 1964 and reported that he had again started drinking and was depressed and moody. Imipramine had been given by his own doctor but did not help, as it made him sleepy. There were no suicidal tendencies. $\mathrm{He}$ was again put on phenelzine and warned not to take phenelzine and imipramine together, to wait for four days after stopping the imipramine before starting the phenelzine, and to bring back the imipramine at his next visit.

On 5 May 1964 he was admitted to hospital with a history of overdosage by both phenelzine (probably 30-40 tablets) and imipramine (abou 20 tablets), and it was also reported that he was drinking heavily. He was in a state of delirium. His pupils were dilated and showed no reaction to light. His pulse was regular at 150 , bloodpressure $160 / 100 \mathrm{~mm}$. $\mathrm{Hg}$, temperature $41^{\circ} \mathrm{C}$ $\left(106^{\circ}\right.$ F.). The neck was rigid and partially extended, while the arms and legs were held rigid. The fingers were extended at the interphalangeal joints and flexed at the metacarpophalangeal joints, and the feet were plantarflexed. Abdominal musculature contracted and firm. Heart sounds were normal. Lungs normal. His condition rapidly deteriorated; his pulse became feeble, irregular, and dropped to $30 / \mathrm{min}$. His temperature rose to $43.2^{\circ} \mathrm{C}$ $\left(110^{\circ} \mathrm{F}.\right)$; and he died one hour after admission. Blood showed the alcohol content to be within a normal range, but the concentrations of phenelzine and of imipramine were at toxic levels. No significant lesions were found in the brain or elsewhere.

-We are, etc., \section{Herts. \\ N. R. PAL.}

\section{REFERENCES}

Davies, G., British med. F., 1960, 2, 1019.

Taylor, D.'C., Lancet, 1962, 2, 401.

Cocks, D. P., and Passmore-Rowe, A., Brit. med. f., $1962,2,1545$.

\section{Oral Contraceptives and Liver Damage}

SIR,-The preliminary communication on "Hepatic Impairment During the Intake of Contraceptive Pills. Clinical Trial with Postmenopausal Women" (15 August, p. 426) has prompted us to comment that in the table the authors clearly demonstrate that the hepatic functional alteration borne out by the serum glutamic oxalacetic transaminase, serum glutamic pyruvic transaminase, and bromsulphthalein is transient in nature. The rise in serum transaminase is striking, but even more so is the fact that the elevated values tend to diminish in some of the cases despite continued administration of Lyndiol.

From the results of the authors there is no doubt that a functional alteration of the liver has occurred in their group of elderly patients, yet the evidence is insufficient to label this as a hepatotoxic effect, nor can one infer that liver damage of any nature has been produced.

The importance of the results reported by Dr. A. Eisalo and his colleagues has prompted us to state that we have in preparation papers on liver-function tests in groups of women on oral contraceptives for over 60 cycles. Also we have on hand the results of S.G.P.T. in 56 women taking the oral contraceptive combination: $5 \mathrm{mg}$. 17ethynyl-oestrenol and $0.15 \mathrm{mg}$. 3-methoxy17-ethynyloestradiol (formulation found in Lyndiol $5 \mathrm{mg}$.).

Serum Glutamic Pyruvic Transaminase

\begin{tabular}{|c|c|c|c|c|}
\hline $\begin{array}{c}\text { Oral } \\
\text { Contraceptive }\end{array}$ & 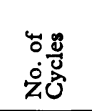 & 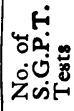 & 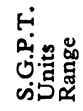 & 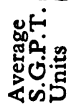 \\
\hline $\begin{array}{l}5 \mathrm{mg} . \quad 17-\text {-ethynyl- } \\
\text { oestrenol and } 0 \cdot 15 \\
\text { mg.3-methoxy-17- } \\
\text { ethynyloestradiol }\end{array}$ & $\begin{array}{cr}\text { Over } 3 \\
\Rightarrow & 6 \\
\Rightarrow & 12\end{array}$ & $\begin{array}{r}20 \\
34 \\
2\end{array}$ & $\begin{array}{r}8-38 \\
7-41 \\
18-42\end{array}$ & $\begin{array}{l}20 \cdot 0 \\
18 \cdot 5 \\
30 \cdot 0\end{array}$ \\
\hline
\end{tabular}

The results of the S.G.P.T. liver-function test in our group of 56 women taking the oral contraceptive combination referred to by Eisalo and his colleagues for more than 3 to more than 12 cycles do not indicate liver damage of any nature.

This in no way is intended to nor can it distract merit from the communication of Eisalo and his colleagues, which refers to results in an elderly group of women and in which the liver-function tests were made on a different schedule. It is presented, none the less, as evidence of the lack of liver-function alteration during prolonged treatment with the same oral contraceptive reported as producing liver damage in elderly women in a short-term trial made by Eisalo and his group. -I am, etc.

Centro de Investigacion EDRIS RICE-WRAY.

de la Pisiologia de la Reproduccion
San Luis Potosi, Piso, Mexico.

\section{Feeding the Phenylketonuric}

SIR,-One of the problems in designing a low-phenylalanine diet for the phenylketonuric toddler is to provide an adequate substitute for bread and biscuits. These can be baked with wheat starch, but the technique is difficult and the bread does not keep well.

I have recently given a newly developed low-protein biscuit (phenylalanine content $10 \mathrm{mg}$. per $100 \mathrm{~g}$.) to several phenylketonuric patients. It may be coated with jam or honey, or decorated with icing sugar; it may be crumbled and mixed with fruit or vegetables ; or even crushed and added to a bottle containing a low-phenylalanine-protein mixture. All patients have taken it well and their mothers have been delighted. This food is made in Holland and marketed by Liga Food Products (U.K.) Ltd., of Leicester. Other doctors treating phenylketonuric patients may be interested.-I am, etc., 